\title{
What's the Use?
}

Robert Neville sticks to the iconoclastic trajectory of theology far more consistently than Celia Deane-Drummand; indeed, among contemporary scholars who self-identify as theologians, he is one of the most consistent followers of this trajectory. I will argue, however, that he is not consistent enough. For readers familiar with Neville's expansive literary corpus, one of the first questions that arises when confronted with Volume One of his trilogy on Philosophical Theology is: how many magna opera can one scholar produce? ${ }^{1}$ For those of us interested in the details and the development of his metaphysical and epistemological hypotheses over the decades, a whole series of more serious intellectual questions also quickly emerge.

My primary interest here, however, is exploring an explicitly pragmatic question: what's the use of Neville's astonishingly consistent and carefully argued theoretical proposal in contemporary contexts shaped by radically pluralistic and globalizing forces? The answer, of course, is: "it depends." As Neville himself makes clear, whether or not a religious symbol carries over the value of ultimate reality in certain respects depends on a whole host of factors, including the purpose, maturity, and community of the interpreter.

The function of religious symbols within an interpretation also depends, however, on the extent to which individuals rely on or learn to contest evolved cognitive and coalitional biases that reinforce the tendency to detect humanlike, coalition-favoring disembodied intentional forces. In the first section of this chapter I examine these dynamics in light of the same heuristic conceptual framework we have been exploring in earlier chapters. As one of the directors of the Institute for the Bio-Cultural Study of Religion, Neville is quite familiar with this literature and in the second section I point out some of the ways in which his theoretical project encourages the contestation of biases toward anthropomorphic symbols authorized by a particular in-group. My main concern, which comes to the forefront in the final section, is the extent to which Neville's "pastoral" practice of allowing (and even insisting upon) the continued use of such symbols for ultimacy can surreptitiously strengthen the superstitious and segregative tendencies he wants to enervate.

1 This chapter is an adapted version of "What's the Use? Pragmatic Reflections on Neville's Ultimates," which was originally published in the American Journal of Theology \& Philosophy 36 , no. 1 (2015).

(C) F. LERON SHULTS, 2018 | DOI 10.1163/9789004360952_010

This is an open access chapter distributed under the terms of the CC BY-NC-ND 4.o license Ron Shults - 9789004360952 
Toward the end of Philosophical Theology Volume One, Neville points to the intrinsic relation between what he calls systematic philosophical theology and systematic practical theology. The latter has the task of determining the truth of symbols of ultimacy in particular contexts. "How can we tell whether popular religion carries over ultimate truth into its practitioners from context to context?... That is, do the symbolic engagements in those contexts have in their practical lives the truth of ultimate reality?" In order to answer such questions, practical theology has to understand not only the context but also the functional network semiotic connections, the relevant iconic and indexical referential dimensions and the extent to which "the individuals and groups are ready or unready for accepting the symbols in a true way. But in order to do any of this, systematic practical theology needs to hold on to the most sophisticated truth possible about what ultimate reality really is." ${ }^{2}$

One of the aspects of Neville's system that I most appreciate is his emphasis on the sense in which all religious symbols "break on the infinite." Insofar as they are intended to refer to finite/infinite contrasts within a sacred canopy, such symbols inevitably break - determinate symbols cannot directly refer to the indeterminate ontological act of creation. For the purposes of this chapter, I am going to assume familiarity with these key aspects of Nevillian ontology and semiotics, referring readers to the relevant resources in the footnotes.

I am also going to assume the reader's familiarity with theogonic reproduction theory, which we have been exploring throughout the earlier chapters. However, it is important to emphasize once again that the mechanisms that promote anthropomorphic promiscuity and sociographic prudery are reciprocally reinforcing. As we have seen, supernatural agents who are cared for and ritually engaged within a coalition are easy imaginative targets for the hairtriggered agency detection mechanisms of each new generation. Extensive cross-cultural empirical research has demonstrated that activating people's anxiety about the welfare of their kith and kin can increase their tendency to interpret ambiguous phenomena as caused by potentially punitive disembodied agents. Conversely, priming individuals with thoughts about possible invisible watchers can reinforce a tendency to protect their in-group and become antagonistic toward out-group members.

2 Neville, Ultimates: Philosophical Theology, Volume One (State University of New York Press, 2014), p. 295. Unless otherwise noted, page numbers in the following paragraphs are from this book.

3 Neville, The Truth of Broken Symbols (State University of New York Press, 1996); Neville, On the Scope and Truth of Theology: Theology as Symbolic Engagement (T \& T Clark, 2006). 
This mutual intensification of superstitious interpretation and segregative inscription happens automatically and unconsciously, all too easily obscuring the powerful covert operations of theogonic reproduction. Understanding this is the key to understanding my concern with Neville's use of religious imagery in his "practical theology."

\section{Neville's Anthropomorphic Prudery and Sociographic Promiscuity}

Like most serious academics, Robert Neville resists explanations of the natural world that appeal to supernatural agents as causal forces. Like most public figures in pluralistic contexts, he also resists appeals to the supernatural authorities of particular in-groups. In fact, this dispositional tendency to contest the evolved cognitive and coalitional biases briefly outlined above is evident throughout Volume One of Philosophical Theology. Already in the Introduction Neville points toward the importance of the biological and social sciences for his project, and hints at themes that will pervade the book, including resistance to privileging "personal" ideas of God and "confessional" approaches to theology. Later in the book he sometimes explicitly incorporates insights from the bio-cultural sciences to support his arguments, as when he points to the role of the tendency to over-attribute agency to non-intentional things in fostering human-like interpretations of ultimate reality (254).

Neville is quite straightforward in his attitude toward anthropomorphic symbols for ultimacy: "We know from the concept of the ultimate as the ontological creative act that God does not have intentions. Metaphysics can tell us when a false inference is being drawn from an anthropomorphic symbol of divinity" (296). He insists that it follows from the concept of the ontological act of creation that it "cannot be internally intentional ... the personal connotations many people have with the term God should be carefully expunged from philosophical theology." However, this sentence is immediately followed by a qualification: "Of course, there might be situations in which highly personified symbols of ultimacy are well used for engaging ultimate reality" (280-281). It is this hasty "of course" that worries me, for pragmatic reasons to which I will return below.

Neville is also straightforward about the societal problems that arise from what I am calling sociographic prudery. For example, he insists that the in-group/out-group distinction is absurd if regarded as ultimately significant. It is also pernicious because "it leads people in the in-group to not pay attention to those in the out-groups, to not observe their diverse narratives and conditions" (158). Such distinctions can intensify anxious and violent reactions to cultural others. "Nevertheless," argues Neville, "the human need 
for intimate connections with the ultimate realities that might be depicted in sacred canopies means that we cannot do without ultimate narratives of some sort and some kinds of anthropomorphic symbols of ultimate realities" (158-159). It is the ease with which Neville asserts this "nevertheless" that worries me; is it really the case that we cannot do without "ultimate narratives" that include anthropomorphic symbols? It seems to me that in a growing number of contexts this is precisely what we must learn to do without.

For the most part, Neville's writings support the integration of anthropomorphic prudery and sociographic promiscuity depicted in Figure 2 (see Chapter 1, p. 64). These forces are theolytic (god-dissolving) because they weaken the mechanisms of theogonic reproduction. Superstitious interpretations and segregative inscriptions are becoming more and more problematic in pluralistic, globalizing contexts. Increasingly, modern people are coming to believe that it is possible to make sense of the cosmos and act sensibly in society without appealing to supernatural agents as causal powers or moral regulators.

As we will discuss in more detail in Chapter 12, this shift is related to the spread of naturalism and secularism, both of which can be conceived as ways of adapting to the challenges of a new socio-ecological environment that is radically different from that of our upper Paleolithic ancestors. Both methodologically and metaphysically (in the sense introduced at the end of Chapter 1), Neville is a naturalist and a secularist.

He is also a theologian. Why is that relevant? Long before the rise of naturalism and secularism the intellectual elite of the large-scale religious traditions that emerged in the wake of the west Asian axial age had begun to think critically about anthropomorphic symbols for the divine. So did the "theologians" of those traditions that emerged out of the south and east Asian axial age traditions, as Neville notes at several places. ${ }^{4}$ The idea of "God" as an infinite disembodied intentional Force was tentatively born(e) in the minds of monotheistic theologians who pressed the evolved biases toward anthropomorphic promiscuity and sociographic prudery to infinity.

This turned out to be too far. They realized that a truly infinite, absolutely transcendent reality could not be represented in the human mind. And so theologians worked hard to break idolatrous symbols, that is images (or icons, in the Platonic, not the Peirceian sense) that pretended to represent the infinite. Ultimacy cannot be conceived (or perceived) as a Person (or anything else). A forteriori it really makes no sense to think of ultimate reality as preferring one

4 See, e.g., Neville ed., Ultimate Realities (State University of New York Press, 2001). 
Polity over another. This "iconoclastic" trajectory in theology presses toward the integration of anthropomorphic prudery and sociographic promiscuity.

On the other hand, as active members of monotheistic coalitions, most theologians have also worked hard to defend hypotheses about the existential conditions for axiological engagement that do involve the interpretation of and ritual interaction with a supernatural Agent who cares for their Group. This latter "sacerdotal" trajectory has been the most dominant in theology by far. Reinforced by (hidden) cognitive and coalitional biases, it has not had much trouble domesticating the iconoclastic urges of even the most rigorous intellectuals, prophetic activists, and devoted contemplatives in those traditions. Moreover, regular believers have always found it relatively easy to ignore theological debates about the unknowable transcendence of God.

As cross-cultural psychological experiments have shown, people may memorize and repeat orthodox doctrinal formulations about God's transcendence (citing attributes like omniscience, omnipotence, and impassibility) but under time constraints or stressful conditions they automatically, and immediately fall back upon "theologically incorrect" interpretations guided by their evolved biases - imaginatively detecting finite gods who are interested in the practical lives, and have just enough power to punish or reward their kith and kin. In other words, even if a religious parishioner (or seminarian) was able to pass an exam on Nevillian metaphysics, as soon as she leaves the room and re-enters her everyday frame of reference she will continue reproducing anthropomorphic god-conceptions that hold her sacerdotal in-group together - unless and until she learns to contest the theogonic mechanisms.

\section{Pragmatic Reflections on Religious Reproduction}

Allowing the covert operations of these evolved biases to continue unchecked all too easily allows people to remain commited to their favored in-group superstitions and antagonistic out-group segregations. This is why I urge "practical theologians" to become more explicitly iconoclastic, and more intentional about pursuing a delicate conversation that is all too tempting to avoid.Postponing "the talk" about where babies come from and what it takes to care for them for too long can have devastating effects. Of course, it can be equally devastating if the conversation makes people feel attacked, afraid, or ashamed. The activities that lead to sexual and religious reproduction can feel terrific to our bodies, but baring our souls about them can feel terribly vulnerable. It is important to be 
sensitive when discussing these intimate issues but, as I have argued in earlier chapters, it is also important to be direct.

As I noted in Chapter 1, having "the talk" about religious reproduction should involve more than simply explaining how "it" works. It is equally important to work out the physical, emotional, and social consequences of "doing it." This is just as true for religious education as it is for sex education. We need a theological version of "the birds and the bees" that deals with the dynamics by which gods are reproduced in human minds, and the consequences of nurturing them in human groups. Part of the problem is that we are socialized not to ask where gods come from; we learn early that it is not polite to ask folks why they keep them around.

Until relatively recently, our understanding of the mechanisms that engender shared imaginative engagement with human-like disembodied agents associated with particular in-groups has been quite limited. The illuminative power of the disciplines that contribute to the bio-cultural study of religion challenges the plausibility of belief in ghosts, gods, and other culturally postulated disembodied intentional forces.

As a systematic philosophical theologian Neville seems to agree. In his efforts as a systematic practical theologian, however, he seems all too willing to allow and even encourage the use of personified religious symbols, even in rituals that have traditionally served to mark off the boundaries of an in-group (such as the Eucharist). In his discussion of worldviews in Chapter 4 of Philosophical Theology, Volume One, Neville suggests that "in most North Atlantic Christian congregations, few people would believe that they could manipulate God, shaman-wise, to get what they want in prayer" (89). Based on my own experience in literally hundreds of evangelical churches over the decades, I would argue the vast majority of religious people in such contexts believe $e x$ actly that. Neville is (understandably) dismissive of interpretations of $9 / 11$ as God's punishment on America for the gays or the feminists (295), but this is precisely the sort of interpretation favored by some of the most tightly bound and fastest growing religious in-groups.

Continuing to foster symbolic engagements that utilize anthropomorphically promiscuous and sociographically prudish images all too easily reinforces the naturally evolved tendency to over-detect agents and over-protect groups. If the philosophical theologian does not explicitly challenge the validity ("truth," in Neville's sense) of such symbols in modern contexts, religious people on the "popular" side of the continuum, which is the vast majority of the population, will go on having unprotected imaginative intercourse within their own religious family of origin and reproducing "theologically incorrect" 
coalition-favoring supernatural progeny. The virtuoso speculative theologian may be an exception. She might theoretically be able to take such symbols in some respect that does not lead to their (mis)use or (ab)use in her social engagement with others.

But if she is also a practical theologian concerned about the real consequences of engaging such symbols within sacerdotal in-groups, why would she? Regardless of what she may say as a philosophical theologian, if she does not explicitly address the deleterious pragmatic effects of continuing to bear supernatural agents in supernatural coalitions in a violent-prone, ecologically fragile world, even those of us who can remember her sophisticated formulations will just smile and nod as we go on detecting the gods of our own group, thereby reinforcing the hidden mechanisms that activate cognitive and coalitional biases that contribute to superstition and segregation. Why not just leave the gods out of (philosophical and practical) theology completely? Why not explicitly encourage people in late modern contexts to avoid any use of anthropomorphically promiscuous and sociographically prudish religious symbols?

In my view, not only is this sort of iconoclastic approach more likely to produce feasible pragmatic strategies for inscribing the socius in pluralistic contexts, it is also more consistent with Neville's own theoretical arguments. The basic thrust of his constructive work over the decades has challenged the personification of God and the authority of monotheistic Groups in thinking about Ultimates. Especially within socio-ecological niches in which survival no longer depends on the detection of gods that protect in-groups, symbolical engagements that incorporate iconic semiotic representations of the latter are (in the Nevillian sense of the terms) not only "broken" - they are "false" insofar as they promote inaccurate superstitious interpretations and aggressive segregative inscriptions that are in no sense "ultimate."

Scholars trained in the monotheistic (and other) traditions that emerged in the wake of the axial age have a unique role to play in the practical theological task to which Neville alludes in Volume One and addresses in more detail in Volume Two (and Three). ${ }^{5}$ As the mechanisms that support the sacerdotal dominance of theology are increasingly unveiled, it will be easier to liberate the productive iconoclastic forces that have long been domesticated within these traditions. Our "pastoral" ministrations will either foster theogonic

5 Neville, Existence: Philosophical Theology, Volume Two (Albany: State University of New York Press, 2015); Neville, Religion: Philosophical Theology, Volume Three (Albany: State University of New York Press, 2016). 
reproduction or promote the sort of theolytic retroduction that engenders naturalism and secularism. In the contexts in which most of us find ourselves, I argue that it makes good sense to become ever more explicit as we invite people to have "the talk" about the causes and consequences of shared symbolic engagement with the gods.

In his response to my original article in the American Journal of Theology and Philosophy, Neville focused mostly on the places where we agreed, and confirmed my assessment that he was a "seasoned practitioner" of a "vigorous iconoclasm" in his theology classes. However, he also wondered whether my proposals were insufficiently sensitive in practical theological contexts. For example, he noted that it would not be practical to refer "an unlettered midwestern Southern Baptist ... to the comfort of Abhinavagupta's ontological Shiva" when he is burying his children. The task at that point is to help "ground a grieving father in what is ultimately important in the face of death." He also described how his own liberal Protestant father explained to him at a young age why the services at the Black Pentecostal church in St. Louis were so "emotional and nonsensical" and included "speaking in tongues"; this was "the only way they had," he said, "to make sense of their lives," and it helped them feel "freer and more purified." Finally, Neville wonders whether I too quickly dismiss people's need to "engage what is ultimately important," and whether I think there is any place at all for the "ecstatic fulfillments" that religion can faciliate.

I will be the first to agree that the hospital room or funeral parlor is not the best time or place to challenge people's religious biases or press them toward a naturalist and secularist worldview. I also happily concede that there are individuals and groups in certain contexts for whom rigorous iconoclasm is not the (immediate) solution. I have made it clear in other writings that I value pastoral sensitivity as well as intensely ecstatic experiences, and that learning how to facilitate these without the need for supernatural beliefs and rituals is one of the most significant challenges (and opportunities) for the non-religious. However, I wonder whether discounting the capacity of emotionally needy, unlettered Baptists for ideological transformation, and condoning the nonsensical behaviors of Black Pentecostals who don't have any better way to make sense of their lives, is more patronizing and ultimately less pastorally sensitive

6 Neville, “Comments on F. LeRon Shults's 'What's the Use? Pragmatic Reflections on Neville's Ultimates," American Journal of Theology and Philosophy 36, no. 1 (2015).

7 Ibid., $83-84$. 
than my suggestion that (outside of overwhelming psychologically distressful situations and alongside the effort to remedy politically oppressive situations) we have "the talk" with people as though they are adults who are capable of thinking critically and altering the ways in which they pursue the intensive ecstasies that life has to offer. 